\title{
COMPARATIVE STUDY OF TWO PEGMATITIC FIELDS FROM MINAS GERAIS, BRAZIL, USING THE Rb AND Cs CONTENTS OF MICAS AND FELDSPARS
}

\section{JOEL QUÉMÉNEUR* AND MARTINE LAGACHE**}

\begin{abstract}
The distribution of alkali elements and F was investigated in minerals of pegmatites and their contact aureole of metasomatism, in two groups of pegmatites from the State of Minas Gerais, southeast Brazil: the Transamazonian-cycle age (1,930 Ma) Volta Grande pegmatites near São João del Rei and the Brasiliano-cycle age (525 Ma) pegmatites of Itinga. The Volta Grande pegmatites are albite and spodumene bearing and their contact aureole of metasomatism, in the amphibolite host rock, are characterized by the presence of holmquistite and zinnwaldite. The Itinga pegmatites correspond to complex lepidolite and pet alite-bearing pegmatites with tourmaline, zinnwaldite and muscovite in their contact aureole developed in quartz-biotite-muscovite-schists. The K-bearing minerals of the Volta Grande pegmatite are exceptionally rich in $\mathrm{Rb}$. Using the experimentally determined partition coefficients between minerals and fluids, the atomic ratio $\mathrm{K} / \mathrm{Rb}$ of the pegmatitic fluid may be evaluated. This ratio shows homogenous values, around 4. Similar values are found in the metasomatic aureole, at the contact, which increase as a function of the distance from the contact, due to the crystallization of trioctahedral micas that deplete the fluid in $\mathrm{Rb}$. The $\mathrm{K} / \mathrm{Rb}$ ratios of the fluid could represent the ratio of the initial pegmatitic magma before differentiation. Rb content in the Itinga pegmatites is much lower and strongly differs from border to core. The presence of K-bearing minerals in the wall rocks contributes for the increasing the $\mathrm{K} / \mathrm{Rb}$ ratios of the neoformed minerals at the contact zone. It is then more difficult to evaluate the $\mathrm{K} / \mathrm{Rb}$ ratio of the initial magma. Considering the composition of the minerals at the border of each pegmatite, it varies from 25 at Urubu to 50 at José de Linto and Xuxa localities. The Itinga pegmatites are clearly poorer in $\mathrm{Rb}$ than the Volta Grande pegmatites. Geochemically, a relationship between the Rb and $\mathrm{F}$ contents in the micas is clearly demonstrated in each group of pegmatites. The situation is more complex for Cs because crystallization of all minerals concentrates $\mathrm{Cs}$ in the fluid. Urubu pegmatite is the only one where pollucite was found in the core. Cs content in K-bearing minerals is higher in the lepidolite of the core and in zinnwaldite of the aureole. $\mathrm{Cs}_{2} \mathrm{O}$ in the Volta Grande pegmatite can be as high as $2 \%$, at 1 meter from the contact, as metasomatic fluids become enriched in Cs while the metasomatism proceeds. This element could be used as guide for exploration of the alkali pegmatites.

Keyords:Brazil, pegmatites, geochemistry, mineral chemistry, mica, feldspar
\end{abstract}

INTRODUCTION The $\mathrm{Rb}$ content and the $\mathrm{K} / \mathrm{Rb}$ and $\mathrm{RB} / \mathrm{Sr}$ ratios have been used for a long time, to estimate the degree of fractionation of granitic and pegmatitic magmas (Heier \& Taylor 1959 , Shaw 1968, Lopes Nunes 1973, Correia Neves 1980). It appeared, in our previous studies (Quéméneur et al., 1993 and Lagache \& Quéméneur997), that the $\mathrm{Rb}, \mathrm{Cs}, \mathrm{F}$ and $\mathrm{Li}$ contents in micas and feldspars of pegmatite and contact aureole, can, amongst others, characterize lithiniferous pegmatites. They are also able to supply information regarding the chemical composition of the metasomatic fluid utilizing coefficients obtained by experiments.

In the present study, $\mathrm{Rb}, \mathrm{Cs}$, $\mathrm{Li}$ and $\mathrm{F}$ are analyzed in the most important potassium minerals. The analyses were performed mainly in micas from two pegmatite groups, Volta Grande and Itinga (State of Minas Gerais, southeast Brazil) and their contact aureole. The analyses were performed with two objectives:

1 - To evaluate the $\mathrm{K} / \mathrm{Rb}$ and the $\mathrm{K} / \mathrm{Cs}$ ratios of the pegmatite fluids from the interior to the exterior of the body using the experimentally defined partition coefficients;

2- To model the behavior of $\mathrm{Rb}$ and $\mathrm{Cs}$ in micas of the contact metasomatic aureole as a function of the inferred pegmatite composition, of the wall rock and the distance of the samples from the contact.

Most analyses of the major elements and of $\mathrm{Rb}, \mathrm{Cs}$ and $\mathrm{F}$ from the minerals were performed by electronic microprobe (CAMEBAX and SX 50). Some analyses of Li have been performed by wet chemical methods.

GEOLOGICAL SCOPE The study was devoted to two pegmatites groups: those of Volta Grande, in the São João del Rei region, and those of Itinga, in the Rio Jequitinhonha Valley, respectively in the southern and northeastern of the State of Minas Gerais (Fig.1).

The pegmatites of Volta Grande field, intrusive into Archaean amphibolites (tholeiitic metabasalts), are probably related to the Transamazonian-cycle age Ritápolis granite, which is contemporaneous with the Tabuões trondhjemite, dated by Quéméneur \& Vidal (1989) at $1931 \pm 20 \mathrm{Ma}$. They are lithiniferous and represent a group with very homogeneous chemical composition. The Volta Grande pegmatites correspond to large lenticular bodies (Fig. 2) elongated parallel to the foliation of the amphibolitic country rocks (Lagache \& Quéméneur 1997).

The Itinga pegmatites, part of the Eastern Pegmatitic Province of Brazil (Paiva 1946), are characterized by a wide typological and geochemical variety (Sá 1977). These pegmatites of Brasiliano-cycle age (525 Ma, Siga Jr. 1984)) are intrusive into biotite- andalusitekyanite- and staurolite-bearing schist (Costa 1987), that correspond to a metamorphosed flysch of the Eocambrian Salinas Formation. They are associated with two micas and tourmaline granites (see Fig. 4). These pegmatites are also lithiniferous but the $\mathrm{Li}, \mathrm{Rb}$ and $\mathrm{Cs}$ contents vary in each zone of each pegmatite body.

THE VOLTA GRANDE PEGMATITES The Volta Grande pegmatites (Lagache \& Quéméneur 1997) form a homogeneous assemblage of large lenticular ore bodies (Fig. 2). For example, the body
A in Fig. 2 measured 1200 X 150 X 20m before mining work. They are generally affected by a weak plunge. The Volta Grande pegmatites present a particular zoning (Quéméneur 1987) rather similar to that described by Göd (1987) in Weinebene, Austria. This consists of an aplitic zone of fine-grained albite in the border, which wraps a principal mass of granitoid aspect composed of spodumene, quartz, albite, microcline and muscovite. At the center of this granitoid zone, exist a lenticular layer of 0.5 to $3 \mathrm{~m}$ thick, composed with large spodumene crystals and intergranular quartz. In their central part, the ore bodies B and $\mathrm{E}$ of figure 2, also contain compact lepidolite lenses. The ore body $\mathrm{F}$ is more evolved, carrying lepidolite as the main mica. These pegmatites are mined for tin and tantalum but are characterized by their enrichment in rubidium $\left(0.8 \% \mathrm{Rb}_{2} \mathrm{O}\right.$ in average of lhe bulk composition). The main accessory minerals are cassiterite, apatite, tantalite, magnetite, microlite and garnet (Guimarães 1950, Francesconi 1972). Beryl is occasional and tourmaline is rare.

A contact aureole is well developed and affects the wall rock amphibolite in a thickness of 2 to $3 \mathrm{~m}$. This aureole that do not contain tourmaline, presents two distinct facies: a thin layer of zinnwalditeglimmerite $(2 \mathrm{~cm}$ thick, locally with some pockets $>100 \mathrm{~cm}$ thickness), and a facies with holmquistite and scattered zinnwaldite of 1 to $3 \mathrm{~m}$ thick that passes to fresh amphibolite (Quéméneur \& Lagache 1994). No propylitic alteration was observed, as described by Morgan \& London (1987) around the Tanco pegmatite in Manitoba, Canada.

Chemistry of micas and K-feldspar Selected chemical analyses of micas and K-feldspar are listed in Table 1. The K-feldspars are gray microcline that can be observed in all pegmatite zones, except in the aplitic zone. This microcline presents a constant $\mathrm{Rb}$ contents $\left(\mathrm{Rb}_{2} \mathrm{O}\right.$ vary from 3.2 to $3.3 \%$ in 12 samples of $\mathrm{A}, \mathrm{C}$ and Minas Brasil bodies analyzed) both in all zones of the same deposit and in different bodies.

Muscovite presents a mean $\mathrm{Rb}_{2} \mathrm{O}$ content of $3.2 \%$, with values varying from 1.9 to $3.4 \%$. The lowest values correspond to samples from the marginal zone. The lepidolite shows exceptionally high $\mathrm{Rb}_{2} \mathrm{O}$ contents $(4.5$ to $5.6 \%)$, with a mean value of $5 \%$. In the outer part of pegmatites, the zinnwaldite from the glimmerite facies contains high $\mathrm{Rb}$ concentrations like those of lepidolite ( 3.5 to $\left.5.5 \% \mathrm{Rb}_{2} \mathrm{O}\right)$. $\mathrm{Rb}$ decreases, in the outer zone, as a function of the distance from the contact. At $1 \mathrm{~m}$ from the contact, the micas do not contain more than $3 \% \mathrm{Rb}_{2} \mathrm{O}$, and become a Li-phlogopite.

The Cs contents are relatively low as compared to those of $\mathrm{Rb}$. Microcline contains between 0.05 and $0.10 \mathrm{Cs}_{2} \mathrm{O}$, muscovite between 0.10 and $0.2 \%$, lepidolite from 0.30 to $0.6 \%$ (average $0.5 \%$ ), and zinnwaldite of the glimmerite facies from 0.4 to $0.6 \%$ (average $0.5 \%$ ). It seems that Cs content increases with the contact distance: the micas of a sample taken at distance around $1 \mathrm{~m}$ from the contact contain as much as $1.04 \%$ Cs2O (mean value). However, Cs content of these micas is always more variable than the Rb content, varying from 0.3 to $2 \% \mathrm{Cs}_{2} \mathrm{O}$. There is a good correlation between $\mathrm{F}$ and $\mathrm{Rb}$ contents in the micas (Fig. 6). 


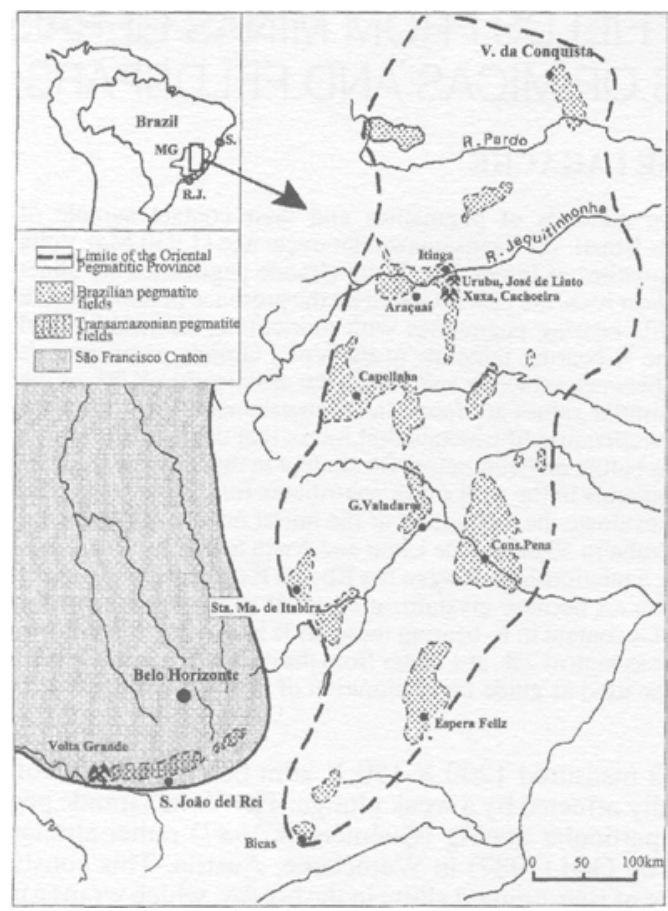

Figure l - Localization of the Oriental Pegmatite Province of Brazil (modified after Putzer 1976).

THE ITINGA PEGMATITES These pegmatites, previously studied by Sá (1977), are divided into two groups:

1 - Lepidolite-bearing complex pegmatites, in the sense of Cerny (1991), characterized by their regular zonation and presence of several lithium minerals.

2 - Albite- and spodumene-bearing pegmatites, which are little differentiated and present a weak to non-existent zonation.

The Urubu, Maxixe and José de Linto pegmatites are part of the first group, while the Xuxa, Cachoeira and Algodão pegmatites as part of the second one. All these pegmatites develop a metasomatic contact aureole that is more prominent in the first group. The complex pegmatites are richer in $\mathrm{Rb}$ than the albite- and spodumene-bearing pegmatites, which in turn are more Li enriched.

THE URUBU PEGMATITE The Urubu pegmatite is the most differentiated pegmatite (Fig. 4), as it present pet alite, amblygonite and pollucite. Geochemically, (Quéméneur et al 1993), it is characterized by relatively high $\mathrm{Rb}, \mathrm{Cs}, \mathrm{F}$ and $\mathrm{Sn}$ (as demonstrated by high abundance of cassiterite) contents.

The metasomatic contact aureole, whose width does not exceed 1 $\mathrm{m}$, is composed of two fades: a first one, 5 to $30 \mathrm{~cm}$ width, with tourmaline and zinnwaldite, and an outer fades, which show zinnwaldite passing into lithiniferous biotite (or phlogopite). The width of this latter is difficult to evaluate, but it is in the order of 50 $\mathrm{cm}$. The tourmaline fades contains also neoformed muscovite.

Geochemistry of the micas and feldspars Selected chemical analyses of micas and feldspar of the Urubu pegmatite are shown in the Table 2. $\mathrm{Rb}, \mathrm{Cs}$ and $\mathrm{F}$ contents of micas and feldspars vary according to their nature and position within the zonation. Muscovites from the margin of the core (Mul) are poor in $\mathrm{Na}$ and $\mathrm{Fe}$, but contain $>1 \% \mathrm{Rb}_{2} \mathrm{O}$. The micas in the intermediate zone (Mu2) and at the border of the pegmatite (Mu3) are richer in $\mathrm{Fe}(1 \% \mathrm{FeO})$ and contain from 0.6 to $0.8 \% \mathrm{Rb}_{2} \mathrm{O}$. The trioctahedral micas such as lepidolitc present higher concentrations of this element than muscovite. The lepidolites of the core ( $\mathrm{Lpl}$ ) contain, locally, up to $2.8 \% \mathrm{Rb}_{2} \mathrm{O}$ (from 2.2 to 2.86 ) and those located in the intermediate zone (Lp2), $<2 \%$. Similar geochemical zonation is observed for K-feldspars. Samples from the intermediate zone near the core (KF2) contain around $0.9 \% \mathrm{Rb}_{2} \mathrm{O}$ and near the border (KF3) around $0.6 \%$.

In the contact aureole, the $\mathrm{Rb}, \mathrm{Cs}$ and $\mathrm{F}$ contents of micas are a function of the distance from the contact, and, to a lesser extent, of their lateral location. At certain points of the contact in the hanging walls, at the roof, the zinnwaldites located in a few centimeters from the roof (sample $\mathrm{Zwl}$ ) have $\mathrm{Rb}_{2} \mathrm{O}$ contents that vary from $0.75 \%$ to
Table 1 - Average chemical composition of some $K$-bearing minerals of the Volta Grande pegmatites: KF1 represents 4 samples of the A body; KF2 corresponds to 3 samples of the Minas Brasil body. Mu] corresponds to 8 probes of the intermediate zone of the A body and Mu 2 to 2 probes of the marginal zone of the A body. Lp1 corresponds to low-Al lepidolite of $E$ and $M$ bodies (2 Probes). Lep 2 represents 4 samples of the $E$ and $B$ bodies. Zwl corresponds to 8 samples of zinnwaldite at the contact from the $A$ body. Zw2 corresponds to 7 samples of zinnwaldite at the contact from the Minas Brasil body; $\mathrm{Li}$-Ph represents 3 samples at $1 \mathrm{~m}$ from the contact. All values are in percentage. *Analyzed by wet chemistry.

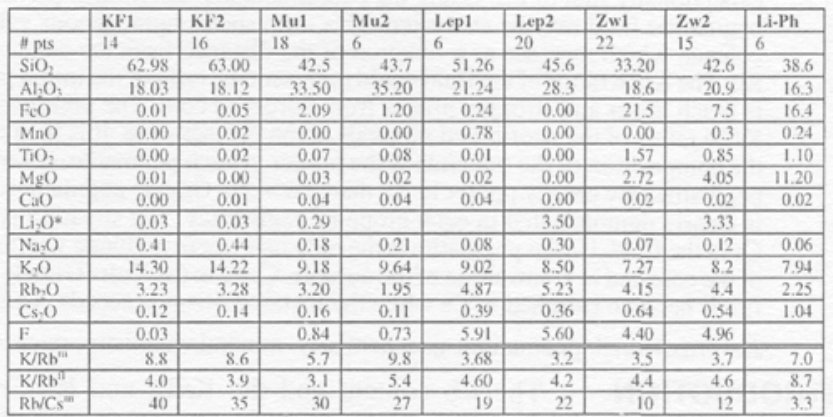

$1.1 \%$. After that point, the contents seem to decrease, as $\mathrm{Rb}_{2} \mathrm{O}$ is around $0.65 \%$ between 10 and $30 \mathrm{~cm}$ from the roof (sample Zw2). The absence of a perpendicular exposition, with respect to the contact of the pegmatitic body, made it impossible to deduce precisely the distance of the sample from the contact.

The neoformed muscovites (Muex) are clearly identifiable by their higher $\mathrm{Rb}$ contents $\left(0.3\right.$ to $\left.0.4 \mathrm{Rb}_{2} \mathrm{O}\right)$ than that from the schist, in which $\mathrm{Rb}_{2} \mathrm{O}$ do not exceed $0.06 \%$. The $\mathrm{Rb}$ contents in the muscovites are about the half of the contents in the zinnwaldites.

The fluorine contents of micas, both trioctahedral and dioctahedral, have positive correlation with $\mathrm{Rb}$ (Fig. 6). They vary from $6-7 \%$ in the lepidolites to $2-3 \%$ for the zinnwaldites and $1-2 \%$ for muscovite. These values are found in trioctahedral micas that have a greater tendency to incorporate $\mathrm{Rb}, \mathrm{Cs}$ and $\mathrm{F}$ in their structure than the dioctahedral micas.

THE JOSÉ DE LINTO PEGMATITE The José de Linto is a pegmatite similar to the Urubu pegmatite, although it seems to be less differentiated, as it contains neither pollucite nor pet alite. It is also an albite-rich pegmatite where K-feldspars occur irregularly in the intermediate zone. These K-feldspars are less rich in Rb and Cs than those of the Urubu pegmatite (Table 3). Pinkish violet lepidolite, red tourmaline and morganite characterize the replacement zone. The columbo-tantalite and cassiterite are the most common accessory minerals.

Thin $(5-20 \mathrm{~cm}$ wide $)$ tourmaline, zinnwaldite and apatite fades and, a fades with neoformed micas (zinnwaldite and muscovite) of $50 \mathrm{~cm}$ thick. Unfortunately, the wall rocks of the pegmatite are weathered and a landslide buries the southern end of the pegmatite.

Geochemistry of micas Selected mineral chemistry data of micas from the José de Linto pegmatite is displayed in Table 3 . The lepidolites (sample $\mathrm{Lpl}$ ) of the central (replacement) zone have $\mathrm{Rb}_{2} \mathrm{O}$ contents varying from 1.8 to $1.95 \%$, while those found in veinlets in the northeastern part of the pegmatite (sample Lp2) contain only 1.4 to $1.5 \% ; \mathrm{Rb}_{2} \mathrm{O}$. The muscovites of the intermediate zone (sample Mu2) present a relatively low and irregular $\mathrm{Rb}_{2} \mathrm{O}$-content, from 0.4 to $0.6 \%$. At the border, muscovite (sample Mu3) has Rb concentration similar to that in the K-feldspars. The neoformed muscovites (sample Muex) from the contact aureole contain around $0.25 \% \quad \mathrm{Rb}_{2} \mathrm{O}$ and the zinnwaldites (sample Zwex) around $0.5 \%$ that corresponds, as at the Urubu pegmatite, to twice the content in the muscovites.

The lepidolites of the central zone $(\mathrm{Lpl})$ have $\mathrm{Cs}_{2} \mathrm{O}$ contents varying from 0.25 to $0.27 \%$, clearly lower than those found in the lepidolite of the Urubu pegmatite $(0.8$ to $0.95 \%)$. However, the $\mathrm{Cs}_{2} 0$ contents are higher in the veinlets of the northeastern end (Lp2), where values up to $0.7 \%$ are found. High values, from $0.6 \%$ to $0.8 \% \mathrm{Cs}, \mathrm{O}$ are observed in the micas (sample Zwin) of a small mixed zone (few $\mathrm{cm}$ thick) exactly at the contact between the pegmatite and the country rock schist.

Likewise in the Urubu pegmatite, the F contents of these micas are roughly proportional to those of $\mathrm{Rb}$, higher concentrations found in the central part of the pegmatite. The zinnwaldites of the small mixed zone 
present high $\mathrm{F}$ contents ( 6 to $7.5 \%$ ), but are relatively poor in $\mathrm{Rb}(0.7 \%$ $\mathrm{Rb}_{2} \mathrm{O}$ ). In the contact aureole, a large part of $\mathrm{F}$ is associated with apatite that is abundant in this zone.

THE XUXA AND CACHOEIRA PEGMATITES These pegmatites have the shape of large size veins with strong plunge. The Xuxa pegmatite is around $900 \mathrm{~m}$ long, and the largest of the four Cachoeira bodies are over $1000 \mathrm{~m}$ long. They are characterized by high abundance of spodumene, rare lepidolite (which is, however, relatively common in the upper western part of the main Cachoeira body), rare tourmaline and pet alite. The bodies are compositionally homogeneous, present almost no zonation and are made up of spodumene, quartz, K-feldspar, albite and muscovite. A metasomatism contact aureole is not as well developed as observed around the pegmatites of the first group. At the Xuxa pegmatite, this aureole consist of a fine layer ( 5 to $10 \mathrm{~cm}$ thick) of black tourmaline and muscovite, followed by a slightly recrystallized zone of 30 to $50 \mathrm{~cm}$ thick with neoformed biotite and muscovite. At the Cachoeira pegmatites, tourmalinization of wall rocks is only observed locally and metasomatism is essentially marked by increase of biotite amounts and high abundance epidote and fluorite. Examinations of samples from drill cores show that wall rock is altered within less than one meter from the contact.

At the Xuxa pegmatite, the $\mathrm{Rb}_{2} \mathrm{O}$ concentration in the muscovites associated with tourmalines in the contact aureole, is low, and varies from 0 and $0.20 \%$. Muscovites can be divided in two categories: type 1 (sample Mul) contains significant high concentrations of $\mathrm{Rb}$ but no $\mathrm{Cs}$, and type 2 (sample $\mathrm{Mu} 2$ ) is relatively rich in $\mathrm{Cs}$ and with no $\mathrm{Rb}$. The two types correspond to two distinct generations: the type 1 muscovite was formed during a first phase, from a Rb-rich, Cs-poor fluid; while the type 2 crystallized in equilibrium with a later fluid depleted in $\mathrm{Rb}$ but enriched in $\mathrm{Cs}$.

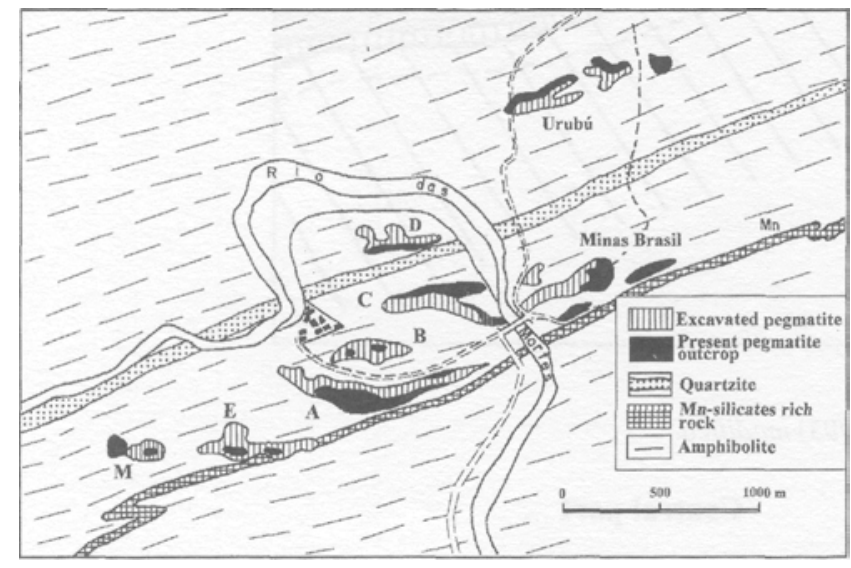

Figure 2 - The pegmatitic field of Volta Grande.

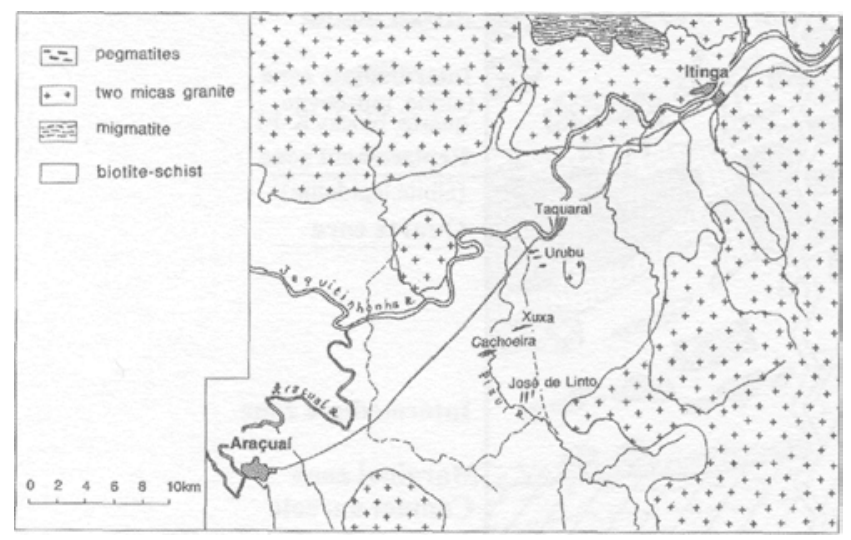

Figure 3 - Geological sketch of the Araçuai - Itinga region.
The muscovites and K-feldspars of the interior of the pegmatite present a slightly richer in $\mathrm{Rb}$ presenting, respectively $0.28 \%$ and $0.23 \% \mathrm{Rb}_{2} \mathrm{O}$.

$\mathrm{Rb}_{2} \mathrm{O}$ and $\mathrm{Cs}_{2} \mathrm{O}$ contents of biotite of the Cachoeira pegmatite aureole, located at $<10 \mathrm{~cm}$ from the pegmatite contact, are, respectively, 0.58 and $0.28 \%$ (sample Bi 1 ), similar to the values found in the José de Linto pegmatite. At $70 \mathrm{~cm}$ from the contact (sample Bi2), the concentration of these elements (respectively 0.055 and $0,005 \%$ ), are not different from those of the regional schist. However, part of these biotites present higher $\mathrm{Cs}$ contents $(0.1$ to $0.2 \%)$, suggesting the high mobility of $\mathrm{Cs}$ and the possible neoformation of these latest minerals.

Minerals of the interior of pegmatite show relatively constant chemical composition. The mean value of the $\mathrm{Rb}_{2} \mathrm{O}$ content is $0.58 \%$ in the $\mathrm{K}$-feldspars and $0.60 \%$ for the muscovites.

GEOCHEMISTRY OF THE PEGMATITE FLUIDS Theevalu ation of the ratios $\mathrm{K} / \mathrm{Rb}$ and $\mathrm{K} / \mathrm{Cs}$ of the pegmatitic fluids in equilibrium with the minerals of the pegmatite and with those of the contact aureole, can be obtained using the experimentally-determined partition coefficients between fluid and minerals, which have been extensively studied for feldspars and micas. Furthermore, some experiments performed on the equilibrium between silicate melt and hydrothermal fluid demonstrated that the partition coefficients of $\mathrm{Rb}$ and $\mathrm{Cs}$ are close to unity (e.g. Carron \& Lagache 1980). Experimental data will then provide information on the composition of minerals and of the fluid coexisting with melt during magmatic crystallization or of fluid that induces re-equilibration of the minerals in the replacement zones of pegmatites or in the exocontact.

The RB and Cs contents of K-bearing minerals are function of the partition coefficient of these elements between fluid and mineral. The partition coefficient for sanidine and micas were experimentally determined by some authors (e.g. Beswick 1973, Lagache 1968, 1969 , Lagache \& Sabatier 1973, Volfinger 1969, 1974). The partition coefficient $\mathrm{P}(\mathrm{X})$ of trace element $\mathrm{X}$ between fluid and mineral can be expressed as follows:

\section{$\mathrm{P}(\mathrm{X}) \mathrm{fl} / \mathrm{mineral}=(\mathrm{K} / \mathrm{X}) \mathrm{fl} /(\mathrm{K} / \mathrm{X}) \mathrm{min}$}

where $\mathrm{K} / \mathrm{X}$ is atomic ratio.

At $600^{\circ} \mathrm{C}$, under a pressure of $1 \mathrm{kbar}$, the following values for $\mathrm{P}(\mathrm{Rb})$ and $\mathrm{P}(\mathrm{Cs})$ were obtained by Volfinger (1974) and Volfinger \& Robert (1980):

$\begin{array}{ll}\text { Sanidine: } & \mathrm{P}(\mathrm{Rb})=0.45 \\ \text { Muscovite } & \mathrm{P}(\mathrm{Rb})=0.55 \\ \text { Phlogopite } & \mathrm{P}(\mathrm{Rb})=1.54 \\ \text { Eastonite } & \mathrm{P}(\mathrm{Rb})=1.11 \\ \text { Annite } & \mathrm{P}(\mathrm{R} b)=2.50\end{array}$

$$
\begin{aligned}
& \mathrm{P}(\mathrm{Cs})=0.02 \\
& \mathrm{P}(\mathrm{Cs})=0.125 \\
& \mathrm{P}(\mathrm{Cs})=0.26 \\
& \mathrm{P}(\mathrm{Cs})=0.125 \\
& \mathrm{P}(\mathrm{Cs})=0.50
\end{aligned}
$$

The partition coefficients for sanidine and muscovite correspond to an enrichment of the fluid in $\mathrm{Rb}$, and for phlogopite and eastonite, to a fluid depleted in $\mathrm{Rb}$. In any cases the fluid is always enriched in Cs.

THE VOLTA GRANDE PEgMATITES Rubidium Micro clines of the Volta Grande pegmatites are remarkable for their regularity regarding the $\mathrm{Rb}$ content, which is independent on the sampling point within the pegmatite, suggesting that the pegmatitic fluids (magma and fluids) were very homogeneous during crystallization. The microcline composition can then provide information on the ratios $\mathrm{K} / \mathrm{Rb}$ of these fluids using the values of $\mathrm{P}(\mathrm{X})$ :

$(\mathrm{K} / \mathrm{Rb})_{\text {mie }}=8.8$

$\left.(\mathrm{K} / \mathrm{Rb})_{\mathrm{n}}=\mathrm{K} / \mathrm{Rb}\right)_{\text {mic }} \times \mathrm{P}(\mathrm{Rb})=8.8 \times 0.45=4$

If we apply the same calculation to a mean value, regarding all the analyses performed of the $\mathrm{Rb}$ content in muscovite and which are not published in this paper (Lagache \& Quéméneur 1997), we found:

$$
(\mathrm{K} / \mathrm{Rb})_{\mathrm{n}}=(\mathrm{K} / \mathrm{Rb})_{\text {musc }} \times(\mathrm{P}(\mathrm{Rb})=6.5 \times 0.55=3.6
$$

The two values for the fluid composition are very similar if one takes in account the fact that the composition of muscovite presents a large scatter. This scatter could be explained by crystallization of the muscovite much more spread in the time than that of K-feldspars, but in equilibrium with a fluid of rather constant composition. There is no real preferential partitioning of $\mathrm{Rb}$ between the two minerals, but, in contrast, the fluid coexisting during their crystallization is weakly enriched in $\mathrm{Rb}$.

There are no experimental partition data for lepidolite. However, using the $\mathrm{K} / \mathrm{Rb}$ ratio measured in the most F-rich compositions of lepidolite from the pegmatite, and the estimated $\mathrm{K} / \mathrm{Rb}$ ratio for the 


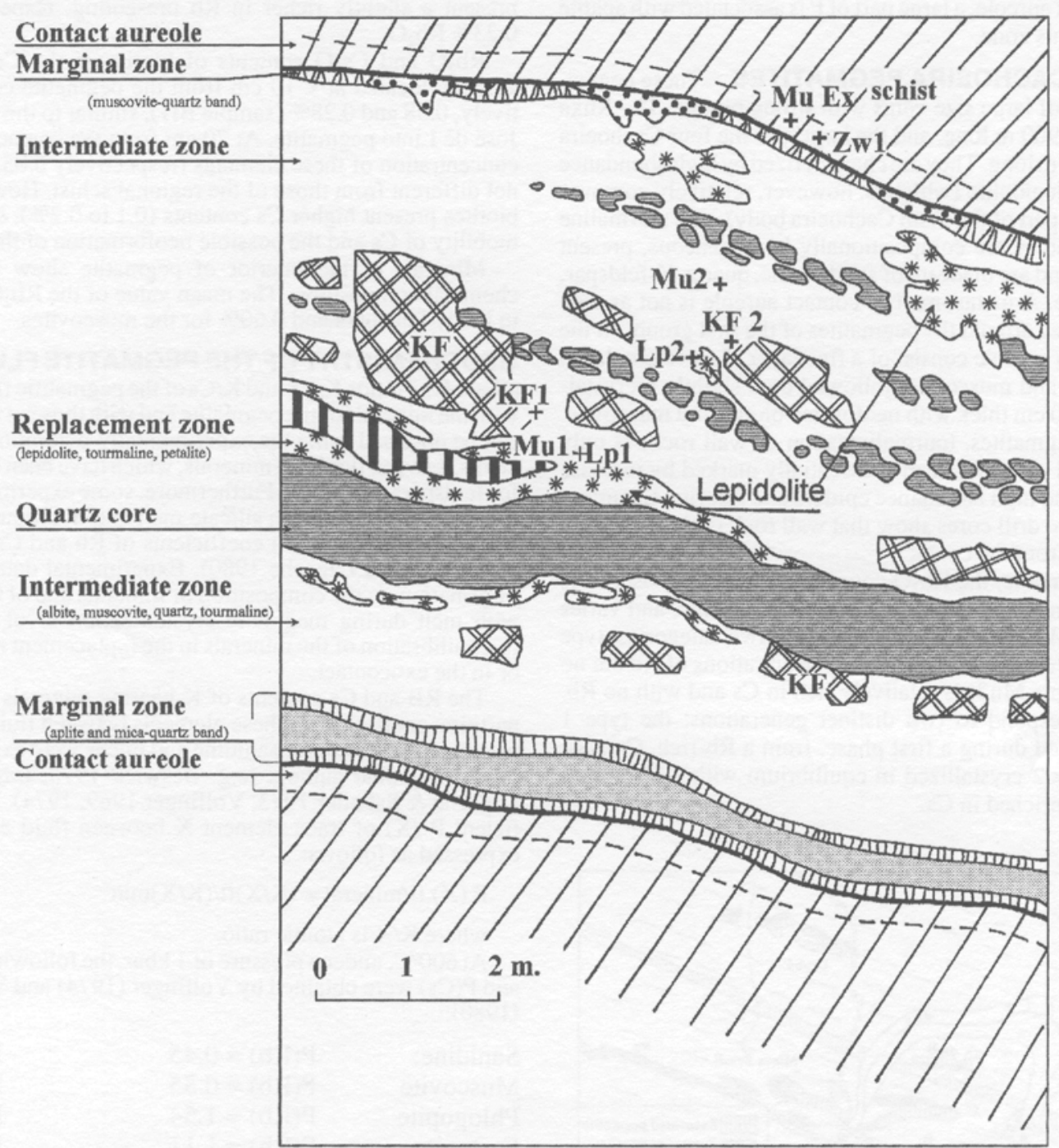

Figure 4 • Sketch section of the Urubu Pegmatite after Quéméneur et al. (1993) modified.

Norther end Intermediate part Central part

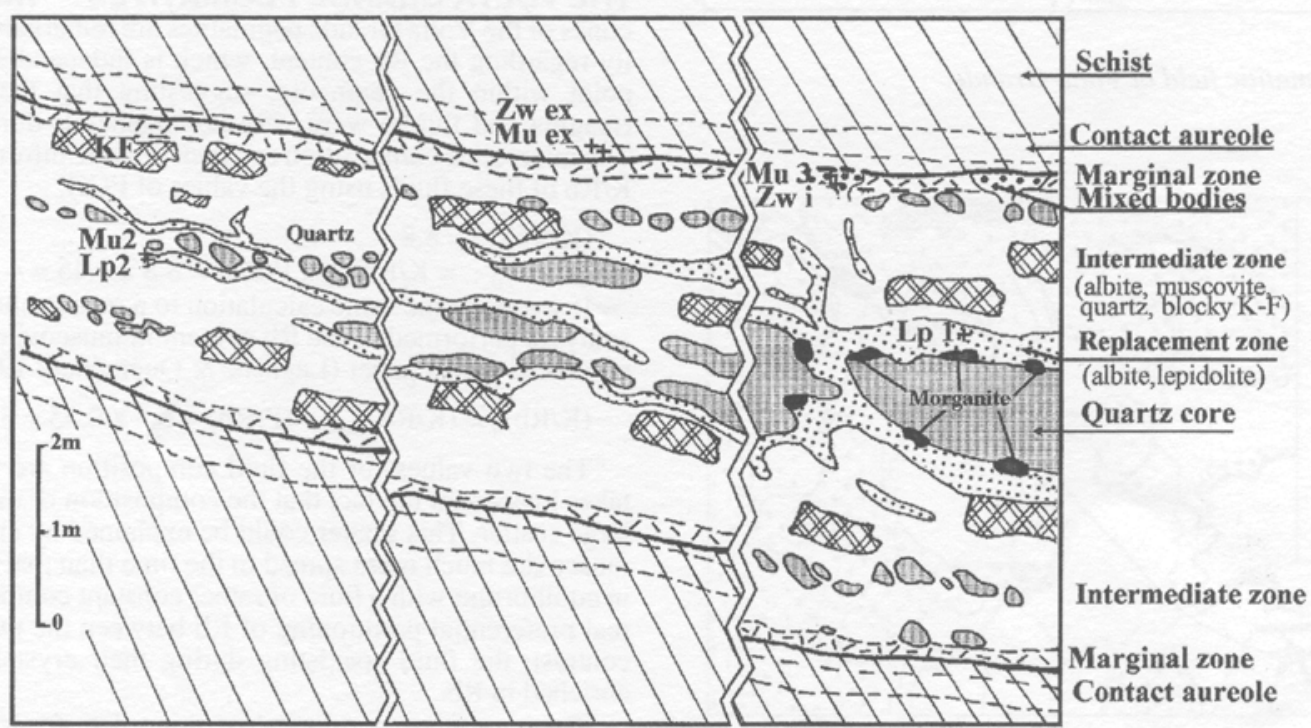

Figure 5 - Sketch sections of the José de Linto pegmatite. 


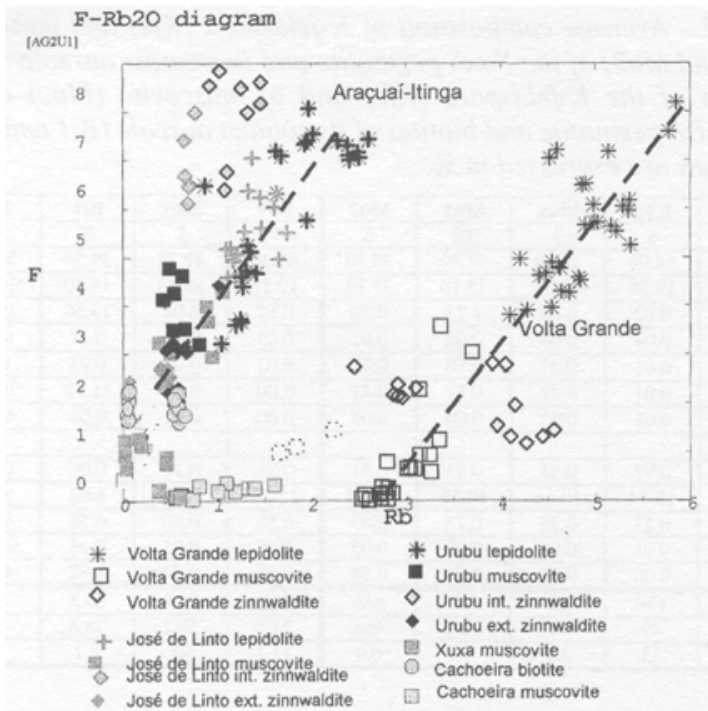

Figure 6 - $\mathrm{F}$ vs. $\mathrm{Rb}_{2} \mathrm{O}$ diagram showing the good correlation between the $\mathrm{F}$ and the $\mathrm{Rb}_{2} \mathrm{O}$ contents of the mica of each pegmatitic field.

fluid, the partition coefficient for Rb between lepidolite and solution can be calculated:

$\mathrm{P}(\mathrm{Rb})_{\mathrm{ri} / \mathrm{lep}}-(\mathrm{K} / \mathrm{Rb})_{\mathrm{n}} /(\mathrm{K} / \mathrm{Rb})_{\text {lep }}=4 / 3.2=1.25$

Lepidolite weakly concentrate $\mathrm{Rb}$, but it contains more $\mathrm{Rb}$ than microcline and muscovite. Our calculated value of 1.25 falls between the coefficients 1.11 and 1.54 obtained experimentally by Volfinger (1974) for the Rb partition between fluid and eastonite and phlogopite. The structure of trioctahedral micas is more favorable to the introduction of large alkali cations. Lepidolite and zinnwaldite are among the few minerals that concentrate $\mathrm{Rb}$ from aqueous fluid.

In the Table 1 , it is indicated the atomic $\mathrm{K} / \mathrm{Rb}$ ratios of the fluid, which have been calculated using the partition coefficients. It is remarkable to observe that the fluid has a constant composition in these pegmatites, which are very homogeneous, as well as in the aureole near the contact.

As the partition coefficient favors the micas, the $\mathrm{Rb}$ content of the metasomatic fluid must decrease progressively during its flow across the exocontact zone. Our analyses of the micas corroborate this conclusion, as the $\mathrm{K} / \mathrm{Rb}$ ratio of the fluid become higher at one meter from the contact. Morgan \& London (1987) have also described this phenomenon around the Tanco pegmatite, Manitoba, Canada.

Cesium The partition coefficient of Cs is very low for sanidine as well as for muscovite, so Cs is strongly concentrated in the fluid. The increase of Cs concentration in the fluid during the course of crystallization is more pronounced as compared to modest increase expected for $\mathrm{Rb}$. The $\mathrm{Rb} / \mathrm{Cs}$ atomic ratio (Table 1 ) decreases from the first generation of pegmatite minerals (microcline and muscovite) to the lepidolite, and muscovite associated with lepidolite, as well as with distance from the contact in the minerals of the metasomatic aureole. It is apparent that some of the most remote micas from the contact are more Cs-rich. The $\mathrm{Rb} / \mathrm{Cs}$ atomic ratio attains very low values, down to 3 , indicating a gradual depletion of $\mathrm{Rb}$ in the fluid due to the zinnwaldite crystallization, and an enrichment of Cs since this is element is invariably partitioned in favor of the fluid. Similar richness in Cs of trioctahedral micas of the contact aureole was described in some pegmatites from eastern Siberia by Glebov et al. (1974).

THE ITINGA PEGMATITES The pegmatites of the first group present e strong differentiation, marked, for example, at the Urubu pegmatites by the presence of pollucite. The $\mathrm{Rb}$ content varies inside the pegmatite. This is particularly clear when a mineral is observed into different parts of the body. For example, muscovite and lepidolite from the central parts of the Urubu and José de Linto pegmatites have a $\mathrm{Rb}$ content higher than those of the border, which almost double between the beginning and end of the pegmatite crystallization. Glebov et al. (1974) described similar Rb variations in Siberian pegmatites.

Thus, at the Urubu pegmatites, muscovite (sample Mu3), which crystallizes early, near the wall rock $(\mathrm{K} / \mathrm{Rb}=45)$ corresponds to a fluid with $\mathrm{K} / \mathrm{Rb}=24.8$. The $\mathrm{KF} 3$ feldspar that is also not far from the contact is in equilibrium with a fluid having a similar $\mathrm{K} / \mathrm{Rb}$ ratio (21.7). Samples KF2, Lp2 and Mu2, in the intermediate zone, are in equilib-
Table 2 - Average chemical composition of K-bearing minerals of Urubu Pegmatite from the core (samples Lpl, Mul) to the border (samples KF3, Mu3) through the intermediate zone (KF2, Mu2, Lp2) and of its contact aureole of metasomatism (Muex, Zw1, Zw2) (see Fig. 4). KF2 corresponds to 3 samples ofmicroclinefrom blacky feldspars. KF3 microcline of the external intermediate zone. Mul corresponds to muscovite associated with lepidolite from 3 samples of the replacement zone. Mu 2 represents 5 samples of muscovite from the intermediate zone and Mu3 2 probes of the upper marginal zone. Muex is muscovite of the contact aureole associated with zinnwaldite. Lpl is lepidolite from 3 samples of the central replacement zone and Lp2 lepidolite from 1 samples of the intermediate zone. Zw1l corresponds to 2 samples from the contact aureole at $5 \mathrm{~cm}$ to the contact and $Z w 2$ to 4 samples of contact aureole at $30 \mathrm{~cm}$ to the contact. All values are expressed in \%.

*Analyzed by wet chemistry.

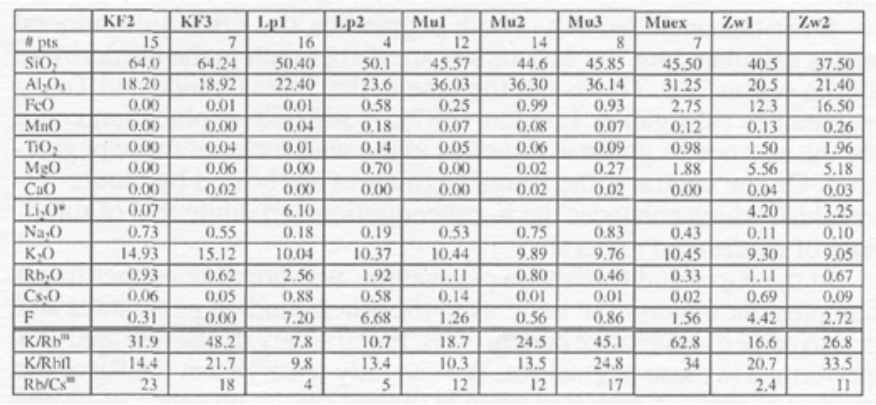

Table 3 - Average chemical composition of the K-bearing minerals of lhe José de Unto pegmatite: Lp1 = lepidolite of the central replacement zone (3 samples); Lp2 = lepidolite of the veinlets from the northern end of the pegmatite (2 samples); MUJ= muscovite of the intermediate zone (2 samples); Mu3 muscovite associated with the zinnwaldite of the mixed zone at the border of the pegmatite (1 sample); Zwi = zinwaldite of the mixed zone in the interior of the pegmatite (2 samples ); Zwex = zinnwaldite of the contact aureole (5 samples) and Muex muscovite associated with Zwex (4 samples). The location of samples is in the Fig. 5. All values are expressed in \%; $*$ obtained by wet chemical analyses

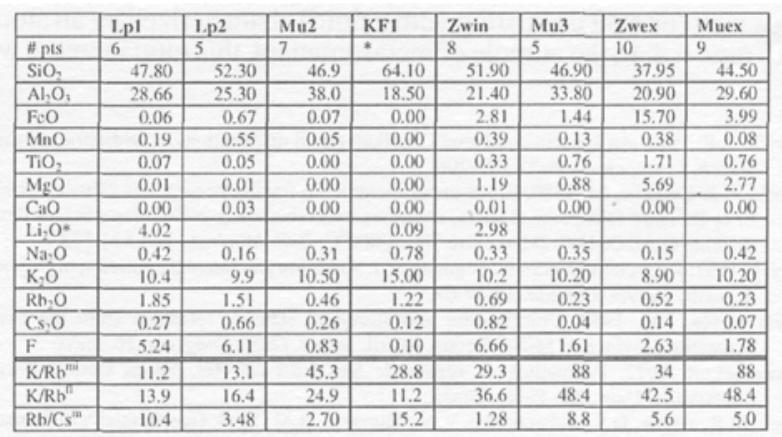

rium with a fluid in which $\mathrm{K} / \mathrm{Rb}=14$. In the center of the pegmatite (samples $\mathrm{Lpl}$ and $\mathrm{Mul}$ ) the $\mathrm{K} / \mathrm{Rb}$ ratio in the fluid is 10 . Inside of the pegmatite the $\mathrm{Rb}$ content of the fluid is enriched by a factor of two, from the beginning to the end of the crystallization. Cs follows similar fractionation process. The Cs content of the samples Lpl and Mul are, respectively, higher than those of the samples Lp2 and Mu2.

At the José de Linto pegmatite, the distribution of $\mathrm{Rb}$ in the minerals is more complex. K-feldspars, which are situated in the intermediate zone, close to the contact zone (Fig. 5), are poor in $\mathrm{Rb}(\mathrm{K} / \mathrm{Rb}=126)$ leading to a fluid with a very high $\mathrm{K} / \mathrm{Rb}(58)$. This could explain a very early crystallization in a first phase. Sample Mu3, situated at the border of the body, corresponds also to a fluid poor in $\mathrm{Rb}$ with $\mathrm{K} / \mathrm{Rb}=48$; it could be contemporaneous with the K-feldspar. In the intermediate zone, the $\mathrm{K} / \mathrm{Rb}$ ratio of the pegmatitic fluid, calculate using the $\mathrm{Mu} 2$ muscovite, is 24 . Lepidolite of the veinlets and from the core (samples $\mathrm{Lpl}$ and Lp2) indicates $\mathrm{K} / \mathrm{Rb}=14$ to 17 in the fluid. Lepidolite is the most fractionated phase of the K-bearing minerals and it shows also the higher Cs content. As in the Urubu pegmatite, the fluid is clearly enriched in $\mathrm{Rb}$ and $\mathrm{Cs}$ as the crystallization proceeds, leading to an important zonation of the chemical composition of the minerals. 
In the contact aureole, the $\mathrm{Rb}$ - and Cs-bearing neoformed minerals are the micas zinnwaldite muscovite and Li-phlogopite or Li-biotite. The zinnwaldites of the Urubu pegmatite has a mean content of $0.67 \%$ $\mathrm{Rb}_{2} \mathrm{O}$, corresponding to $\mathrm{K} / \mathrm{Rb}$ atomic ratio $=26.8$. The muscovite associated with the zinnwaldite has a mean content of $0.33 \% \mathrm{Rb}_{2} \mathrm{O}$ $(\mathrm{K} / \mathrm{Rb}=63)$. Both minerals have probably crystallized from the same solution, whose composition may be obtained by the partition coeffimuscovite $(\mathrm{P}=0.55)$ and $\mathrm{K} / \mathrm{Rb}_{\mathrm{n}}=33.5$ for the fluid in equilibrium with zinnwaldite, using the partition coefficient $\mathrm{P}=1.25$ calculated for the lepidolite at the Volta Grande pegmatite. These very similar compositions allow us to confirm the assumption of simultaneous crystallization of these micas.

Comparable results were obtained at the José de Linto pegmatite, with high $\mathrm{K} / \mathrm{RB}$ ratios in the zinnwaldites as well as in the neoformed muscovites. The $\mathrm{K} / \mathrm{RB}$ ratios in the fluid reach values between 40 and 50.

It can be concluded that in both pegmatites, the $\mathrm{K} / \mathrm{Rb}$ fluid-mineral ratios calculated for the exocontact are higher than in the border zone of the pegmatites. This is not the case in the Volta Grande and Tanco pegmatites (Morgan \& London 1987). A possible explanation could be the absence of potassic minerals in the wall rocks of those pegmatites. On the contrary, the Itinga pegmatites are hosted by biotite-micaschist, which enhances the K concentration and dilute that of rubidium of neoformed minerals.

In the Xuxa and Cachoeira pegmatites, was possible neither to get samples nor identify the body as in the others studied pegmatites and it is to early to generalize conclusions, based solely on the few analyses performed in those pegmatites. We can only observe that the $\mathrm{Rb}$ of the contact aureole of metasomatism is diluted by the presence of biotite and muscovite in the host rock.

CONCLUSIONS We presented two examples of rare-element granitic pegmatites enriched in $\mathrm{Li}, \mathrm{Rb}$ and $\mathrm{Cs}$ (Volta Grande pegmatite) and $\mathrm{Li}$ and $\mathrm{Cs}$ (Itinga pegmatite). In both, the high concentration of $\mathrm{Li}$ resulted in the crystallization of spodumene (or pet alite at the Urubu pegmatite) and lepidolite, as well as zinnwaldite and holmquistite in the metasomatic contact aureole.

$\mathrm{Rb}$ is widespread in K-bearing minerals and the $\mathrm{K} / \mathrm{Rb}$ atomic ratio can reach values as low as 3 at the Volta Grande pegmatite. The partition coefficients between fluid and mineral were then used to account for the distribution observed. Our data permit to infer that the crystallization at the Volta Grande pegmatite took place in a homogeneous melt (or melt coexisting with a fluid) characterized by an atomic $\mathrm{K} / \mathrm{Rb}$ ratio $=4$. In the aureole of metasomatism, this ratio increase with cients. $\mathrm{A} \mathrm{K} / \mathrm{Rb}=34$ was obtained for the fluid in equilibrium with

Table 4 - Average composition of K-feldspars (Kfx) and muscovite (Mu1 and Mu2) of the Xuxa pegmatite and its contact aureole. Composition of the K-feldspars (Kfc) and of muscovite (Muc) of the Cachoeira pegmatite and biotites of its contact aureole (Bil and Bi2). All values are expressed in \%.

\begin{tabular}{|c|c|c|c|c|c|c|c|c|}
\hline & $\mathrm{KFx}$ & Mux & Mu1 & Mu2 & $\mathrm{KFc}$ & Muc & Bi1 & $\mathrm{Bi} 2$ \\
\hline \#pts & 5 & 4 & 10 & 6 & 7 & 5 & 9 & 5 \\
\hline $\mathrm{SiO}_{2}$ & 64.06 & 45.30 & 44.40 & 44.70 & 63.30 & 49.18 & 39.50 & 38.70 \\
\hline $\mathrm{Al}_{2} \mathrm{O}_{3}$ & 18.36 & 37.01 & 35.10 & 37.10 & 19.13 & 33.88 & 15.90 & 16.40 \\
\hline $\mathrm{FeO}$ & 0.02 & 0.60 & 1.73 & 0.88 & 0.02 & 2.04 & 13.50 & 19.80 \\
\hline $\mathrm{MnO}$ & 0.04 & 0.03 & 0.06 & 0.02 & 0.02 & 0.11 & 0.17 & 0.23 \\
\hline $\mathrm{TiO}_{2}$ & 0.01 & 0.03 & 0.60 & 0.17 & 0.02 & 0.199 & 0.93 & 1.12 \\
\hline $\mathrm{MgO}$ & 0.01 & 0,04 & 0.81 & 0.31 & 0.00 & 0.02 & 11.18 & 10.60 \\
\hline $\mathrm{CaO}$ & 0.01 & 0.02 & 0.00 & 0.05 & 0.00 & 0.01 & 0.04 & 0.01 \\
\hline \multicolumn{9}{|l|}{$\mathrm{Li}_{2} \mathrm{O}$} \\
\hline $\mathrm{Ni}_{2}{ }_{2} \mathrm{O}$ & 0.97 & 0.54 & 0.53 & 0.51 & 0.71 & 0.17 & 0.06 & 0.05 \\
\hline $\mathrm{K}_{2} \mathrm{O}$ & 15.24 & 10.36 & 10.39 & 10.65 & 15.27 & 11.12 & 8.93 & 9.52 \\
\hline $\mathrm{Rb}_{2} \mathrm{O}$ & 0.23 & 0.28 & 0.15 & 0.03 & 0.58 & 0.60 & 0.58 & 0.06 \\
\hline $\mathrm{Cs}_{2} \mathrm{O}$ & 0.01 & 0.09 & 0.00 & 0.05 & 0.06 & 0.01 & 0.28 & 0.005 \\
\hline$F$ & $0.00)$ & 0.30 & 0.74 & 0.54 & 0.00 & 0.04 & 1.92 & 1.98 \\
\hline $\mathrm{K} / \mathrm{R} \mathrm{h}^{\mathrm{nz}}$ & 130 & 75 & 137 & 846 & 52.3 & 36.8 & 30.8 & 332 \\
\hline K/Rbll & 49 & 41 & 75.5 & 465 & 23.5 & 20.2 & 38.6 & 415 \\
\hline $\mathrm{Rb} / \mathrm{Cs}^{\mathrm{m}}$ & 35 & 4.7 & & 0.9 & 14.7 & 91 & 3.1 & 18 \\
\hline
\end{tabular}

the distance from the contact, by the crystallization of trioctahedral micas, which deplete the fluid in Rb. Crystallization of the pegmatites of the Itinga pegmatite group is more differentiated and it is possible to observe the decrease of the $\mathrm{K} / \mathrm{Rb}$ ratio with the evolution of the crystallization, and the increase with the contact aureole.

$\mathrm{Cs}$, as well as $\mathrm{Rb}$, concentrates in the fluid but pollucite can eventually crystallize (as at the Urubu pegmatite) in the more evolved part of the pegmatite. In the metasomatic aureole, Cs reaches high concentrations as in zinnwaldites from the Volta Grande or Urubu pegmatites. The atomic ratio $\mathrm{Rb} / \mathrm{Cs}$ can be used to characterize the different fields of pegmatites. At the Volta Grande pegmatite, $\mathrm{Rb} / \mathrm{Cs}$ is relatively high and homogeneous, except in the contact aureole. At the Urubu and mainly at the José de Linto pegmatites, the ratio is much lower, and reach values as low as 1 in zinnwaldite. At the Xuxa and Cachoeira pegmatites, the contents are too low to be representative, and the ratio can not be calculated.

Acknowledgments To PRPq of UFMG and FINEP by the financial support. We are grateful to the mining companies, particularly the MIBRA at Volta Grande, the ARQUEANA at Urubu, José de Linto and Xuxa, and CBL at Cachoeira pegmatites. To the referees of RBG for their suggestions and critical review of the original.

\section{References}

Beswick, A.E. 1973. An experimental study of alkali met al distributions in feldspars and micas. Geoch. Cosmoch. Acta, 37:183-208.

Carron.J.P. \& Lagache, M. 1980. Etude cxperimenlale du fraclionnement des elements Rh, Cs, $\mathrm{Sr}$ et $\mathrm{Ba}$ entre feldspaths alcalins, solutions hydrothermalcs et liquides silicates dans Ic systome Q.Ab.Or.HzO $2 \mathrm{kbar}$ cntrc $700 \mathrm{ct} 800^{\circ} \mathrm{C}$. Bull. Mineral, 103:571-578

Cerny, P. 1991. Rare-clement granitic pegmatites. I. Anatomy and internal evolution of pegmatite deposits. Geosci. Canada, 18:49-67.

Correia Neves, J.M. 1980. Composition and structural state of feldspars from the eastern pegmatite province of Minas Gerais, Brax.il. Intern. Geol. Congress, 26, Paris.

Francesconi, R. 1972. Pcgmatitos da região de São João del Rei, Minas Gerais, doctoral dissertation, Univ. São Paulo, Brazil.

Glcbov, M.P.; Glyuk, D.S.; Sabachcnko, V.N.; Shmakin, B.M. 1974. Geochemistry of formation of cesium mica aggregates in amphibolitcs. Geochemistry International, 937-943. (Trans. of Gcokhimiya, 9:1340-1348).

Guimarães, D. 1950. A ja/.ida de djalmaila de Volta Grande, Rio das Mortes, Minas Gerais. An. Acad.Bras. $C L, 22(1): 51-71$

Göd, R. 1987. The spodumenc deposit at Wcincbenc, Koralpc, Austria, Mineral. Deposita 24:270-278.

Hart, S.R. \& Aldrich, L.T. 1967. Fractionation of potassium/rubidium by amphibolcs: implications regarding mantle composition Nature, 155:325-327.

Hcier, F. \& Taylor, S. 1959. Distribution of $\mathrm{Li}, \mathrm{Na}, \mathrm{K}, \mathrm{Rb}, \mathrm{Cs}$, and $\mathrm{Pb}$ in southern Norwegian Prccambrian alkali feldspars. Geoch. Cosmoch. Acta, 15:284-304.

Heinrich, E.W. 1964. Tin-tantalum lithium pegmatites of the São João del Rei district, Minas Gerais, Brazil. Earn Geol. 59:582-1002.

Lagache, M. \& Quéméncur, J. 1997. The Volta Grande pegmatites, Minas Gerais, Brazil: an example of rare-clement granitic pegmatite exceptionally enriched in lithium and rubidium. Can. Mineral., 35:153-165.

Lagache, M. 1968. Elude cxpcrimenlalc de la repartition des elements en traces cntrc la Icucitc, $1^{\prime}$ 'orthose ct des solutions hydrothermalcs. Lc rubidium à $600^{\circ}$ C. C.R. Acatl. Sci. Paris, 268:1241-1243.

Lagache, M. \& Sabaticr, G. 1973. Distribution des elements Na, K, Rb ct Cs à 1'ctat dc traces cntrc feldspalhs alcalins ct solutions hydrothcrmales à 650"C, Ikbar: donncs cxperimcnlalcs ct interpretation thermodynamiquc. Geoch. Cosmoch. Acta, 37:2617-2640.
Lopes Nunes, J.E. 1974. contribution à 1'élude minéralogiquc et géochimique dcs pegmatites du Mo/.ambiquc. Sciences de Ia terre. 28:1 -201.

Morgan, G. \& London, D. 1987. Alteration of amphibolilic wall rocks around the Tanco rare-clement pegmatite, Bcrnic Lake, Manitoba. Amer. Mineral., 72:1097-1121.

Paiva, G. 1946. Províncias pcgmalílicas do Brasil. Bolt. CPRM-DNPM, 18.

Put/cr, H. 1976. Mctallogenctische Provin/cn in Südamcrika. E. Schweitzenhart'che Verlagshuchhandlung, Stuttgart, $318 \mathrm{p}$.

Qucmdncur, J. 1987. Petrography of the pegmatites of the Rio das Mortes Valley, South cast Minas Gerais, Bra/il. Proc. ISGAM, Rev. Bras. Geoc., 17:595-600.

Quéméncur, J. \& Lagachc, M. 1994. La holmquislitc de Volta Grande pros de São João del Rei, Minas, Gerais, Brcsil: caraclcristiques chimiques et minèralogiqucs. Geonomos, 2(2): $15-21$

Qucmencur, J.; Lagachc, M.; Correia Neves, J.M. 1993. La pegmatite Urubu, Araçuaí, Minas Gerais, Brcsil, exemple de pegmatites complexo à pétalitc: y.onalilé mincialogiquc et gcochimic des micas cl tourmalines. C. R. Acad. Sei. Paris, 317:1425-1431.

Qucmencur, J. \& Vidal, P. 1989. Primeiras datações radiomctricas dos granitos da região de São João dei Rei (MG), An. 5 Simpósio Geol. Minas Gerais, 50-59.

Sá, J.H. de 1977. Pegmatitos litiniferos da região de Ilinga-Araçuaí. Ph. D. thesis, USP, São Paulo, Bra/.il, 112p.

Shaw, D.M. 1968. A review of K-Rb fractionation trends by covariant analysis. Geochim. Cosmoclnm. Acta, 32:573-601.

Volfingcr, M. 1969. Partagc dc Rb ct Cs cntrc sanidinc, muscovitc ct solutions à $600^{\circ} \mathrm{C}-1(\mathrm{~K}) 0$ bars.C.fl. Acad. Sci. Paris, 269:1-3.

Volfingcr, Earth ami Planet Sci. Letters, 24:299-304.

Volfingcr, M. \& Robert, J.M. 1980. Structural control of the distribution of trace elements between silicates and hydrothcrmal solutions. Geoch. Cosmoch. Acta, 44:1455-1461.M. 1974. Eflct dc la composition des micas trioctaedriques sur les distributions dc Rb ct Cs à 1'étal dc traces.

Manuscrito A-1047 Recebido em 01 de dezembro de 1997 Revisão dos autores em 30 de outubro de 1998 Revisão aceita em 05 de novembro de 1998 